\title{
Streptococcus gallinarum sp. nov. and Streptococcus oralis sp. nov.
}

\author{
P. D. BRIDGE AND P. H. A. SNEATH \\ Department of Microbiology, Leicester University, Leicester, LE1 7RH, England
}

Received 22 February 1982/Accepted 2 September 1982

\begin{abstract}
A numerical taxonomic survey of numerous strains of streptococci showed the presence of two clusters of strains that are distinct from the presently named species of Streptococcus. One group, from chicken intestines, is named $S$. gallinarum and the other, from the human mouth, is named $S$. oralis. The type strains are F87/276 (= PB21 $=$ NCTC 11428) and LVG $1(=$ PB182 $=$ NCTC 11427), respectively.
\end{abstract}

As the result of a numerical taxonomic survey of 202 strains of streptococci and closely related organisms (P. D. Bridge, Ph.D. thesis, University of Leicester, 1981), two phenetic groups of strains were observed that were distinct from those representing known species (8) of Streptococcus. These groups were referred to as chicken group D and oral group II.

The chicken group D strains were isolated by Barnes et al. (2) while investigating the effects of dietary bacitracin on fecal streptococci in young chicks. These strains showed properties distinct from those of the established enterococci. They were detected only after a long incubation period (8 days) on a selective medium. The oral group II strains were studied by Carlsson (3) in a numerical taxonomy of streptococci isolated from the human oral cavity. Through the kindness of E. M. Barnes and J. Carlsson, strains were made available for study, and the evidence is presented here for considering these as two new species of Streptococcus. Certain previously named species of the genus do not appear on the Approved Lists of Bacterial Names (11), and these names are placed in quotation marks in this paper.

\section{MATERIALS AND METHODS}

Bacterial strains. The 17 strains of chicken group D and the 13 strains of oral group II are as follows: Chicken group D strains PB18 through PB34 are, respectively, the strains of Barnes et al. (2) numbered F87/273 through F87/279, F87/296, F87/307, F87/311, F87/344, F87/358, F87/361, F87/362, and F87/364 through F87/366. Oral group II strains PB177 through PB190 are, respectively, those of Carlsson (3) numbered KPE2, MVE1, KPE1, LPA1, MPA1, LVG1, OS51, LV51, NS51, OP51, NT61, PT51, and LV81.

Cultural determinants. Cultures were stored at $-80^{\circ} \mathrm{C}$ on glass beads (5). Strains in the laboratory were grown on a basal medium of blood agar base no.
2 (Difco Laboratories) with the addition of $7.5 \%$ (vol/ vol) horse blood (Difco) or on broth medium consisting of (in grams per liter): proteose peptone (Difco), 15; sodium chloride, 5; yeast extract (Difco), 5; and liver digest (Oxoid Ltd.), 2.5. Acid production from carbohydrates was observed in API 50E galleries (API System Ltd.) inoculated with API media and incubated at $35^{\circ} \mathrm{C}$ for $48 \mathrm{~h}$. Standard methods were used for the following: Gram stain; hemolysis on horse blood agar; resistance to $60^{\circ} \mathrm{C}$ for 15 and $60 \mathrm{~min}$; growth at 4 , 10 , and $45^{\circ} \mathrm{C}$; growth at pH 9.6; growth with 3 and $6.5 \%(\mathrm{wt} / \mathrm{vol}) \mathrm{NaCl}, 0.0004 \%$ (wt/vol) crystal violet, and $0.1 \%$ sodium azide; reduction of tellurite, tetrazolium, methylene blue in milk, and nitrite; hydrolysis of arginine, hippurate, and esculin; decarboxylation of lysine; final pH in glucose broth; dextran formation; and gelatin liquefaction (details for these, and for other tests used in the numerical taxonomy, are given by P. D. Bridge, Ph.D. thesis).

Growth on thallous acetate-tetrazolium agar was tested as described by Barnes (1) with the exception that Oxoid neutralized bacteriological peptone was used in place of Evans peptone; cultures were incubated at $35^{\circ} \mathrm{C}$ for $24 \mathrm{~h}$ and then at room temperature for 7 days.

DNA was extracted and purified by the method of Garvie (6) with minor adaptations. Melting point determinations were made in standard saline citrate buffer. The denaturation curves were followed with a Beckman model 35 spectrophotometer with a Stanton Redcroft linear temperature variable rate programmer and an Edale thermistor thermometer with a Grant Instruments temperature probe.

The numerical taxonomy of the 202 strains was based on 157 tests with the Gower coefficient and unweighted pair group method with averages (UPGMA) clustering (14). The test for distinctness of clusters was the $W$ statistic (12); a computer program was used that utilizes the intercentroid distance and standard deviations along the intercentroid axis (13). The method permits a significance test to determine whether overlap is significantly less than that expected from arbitrary division of a continuous variation, referred to as a rectangular distribution (12). 


\section{RESULTS}

The strains of chicken group D clustered as a separate group at the $90 \%$ similarity level (Fig. 1a). They were most closely linked to "Streptococcus avium" (10). They are allied to the classical enterococci $S$. faecalis and $S$. faecium but are not closely related to other species sometimes included among the enterococci, such as $S$. bovis and $S$. equinus. The chicken group D cluster is well separated from " $S$. avium." The disjunction coefficient $W$ between the two clusters was 2.75 , corresponding to a nominal overlap of less than $0.7 \%$. Because of the small numbers of strains in the "S. avium" cluster, it is not possible to prove that this separation is statistically less than a rectangular one (12), for which $W$ is close to 1.7 (or a little higher when numbers of strains are small), and the overlap is about $8 \%$ (or a little lower for small numbers of strains). The test results, however (Table 1), leave little doubt that the groups are distinct.

The strains of oral group II formed a cluster at the $84 \%$ similarity level (Fig. 1b). This was closest to "Streptococcus milleri" (7), but the W coefficient between the two was 6.24 , corresponding to a nominal overlap of $10^{-9}$ and significantly less than that for a rectangular distribution.

The other species that were close were $S$. mitis and $S$. sanguis. The $W$ value between $S$. sanguis and oral group II was 2.62 , which indicates overlap of less than $0.9 \%$, but again statistical significance against the rectangular distribution was not achieved because of the small number of strains of $S$. sanguis. The test results (Table 2) show, however, a sufficient number of differences to support their distinctness. The separation of oral group II from $S$. mitis (and from other oral groups such as $S$. mutans and $S$. salivarius), was highly significant.

The results of the physiological tests and DNA base ratios for the new species and those similar to them are given in Tables 1 and 2. The results for the growth of strains of chicken group $D$ on thallous acetate-tetrazolium agar are shown in Table 3.

\section{DISCUSSION}

The distinctness of the two new species clusters (shown by Fig. 1 and the overlap statistics) is as good as that for traditional species of Streptococcus. Although uniquely defining characters are few or absent, this is also true for existing species (Tables 1,2 ). Neither of them appears to correspond to a previously named species.

The chicken group D strains were noted by Barnes et al. (2) because of their slow growth at

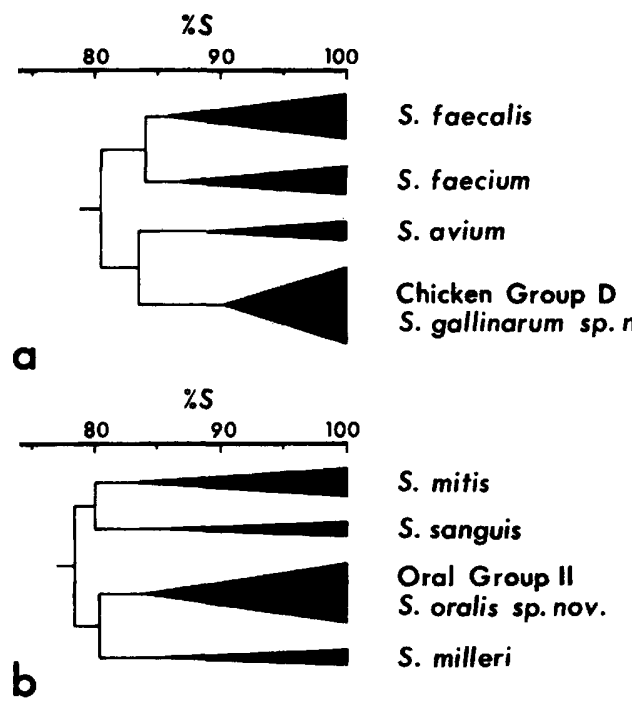

FIG. 1. Dendrograms showing the relations of the new species of Streptococcus to similar species, based on the Gower similarity coefficient and unweighted pair group method with averages (UPGMA) clustering. (a) Chicken group D; (b) Oral group II.

room temperature on thallous acetate-tetrazolium agar, on which they produce pink colonies (a property which we confirmed, Table 3 ). They were of serological group D but did not react with group $Q$ antiserum, unlike "Streptococcus avium" (10). Barnes et al. (2) divided their isolates into three groups, $\mathbf{A 1}, \mathbf{A 2}$, and $\mathbf{A 3}$, based on arginine hydrolysis and inulin fermentation, but in our study there were no distinct subclusters that reflected these tests. Barnes et al. noted that cells of the strains tended to be more pointed and pleomorphic than those of $S$. faecalis and $S$. faecium.

Twenty-three tests used in this study of the chicken group D strains are comparable to those used by Barnes et al. (2). Table 4 shows a comparison of the results. The results of most tests are in good agreement. Barnes et al. (2) used tube methods for the production of acid from carbohydrates incubated for 7 days at $37^{\circ} \mathrm{C}$, with bromcresol purple as $\mathrm{pH}$ indicator, which only responds to acidity below about $\mathrm{pH}$ 5.8. The results here are from API 50E galleries incubated at $37^{\circ} \mathrm{C}$ for $48 \mathrm{~h}$, with phenol red as indicator. Although the incubation time was shorter, phenol red detects acidity at about $\mathrm{pH}$ 6.8 , and it may be that the higher percentage of positive carbohydrate reactions in this study (Table 4) was due to detection of smaller amounts of acidity in the API galleries.

The discrepancy seen in the reduction of methylene blue milk may be accounted for by 
TABLE 1. Test results for $S$. gallinarum and similar organisms ${ }^{a}$

\begin{tabular}{|c|c|c|c|c|c|c|}
\hline \multirow[b]{2}{*}{ Test } & \multicolumn{6}{|c|}{$\%$ Positive } \\
\hline & $\begin{array}{l}\text { S. faecalis } \\
\text { (10 strains) }\end{array}$ & $\begin{array}{l}\text { S. faecium } \\
\text { (6 strains) }\end{array}$ & $\begin{array}{l}\text { "S. avium" } \\
\text { (4 strains) }\end{array}$ & $\begin{array}{l}\text { S. gallinarum } \\
\text { sp. nov. (17 } \\
\text { strains) }\end{array}$ & $\begin{array}{c}\text { S. bovis } \\
\text { (4 strains) }\end{array}$ & $\begin{array}{l}\text { S. equinus } \\
\text { (4 strains) }\end{array}$ \\
\hline Hemolysis $^{b}$ & 40 & 83 & 100 & 100 & 50 & 25 \\
\hline Reduction of tellurite & 100 & 50 & 50 & 18 & 0 & 0 \\
\hline Reduction of methylene blue & 100 & 67 & 25 & $\mathbf{0}$ & $\mathbf{0}$ & 0 \\
\hline Arginine hydrolysis & 100 & 100 & 29 & 0 & 0 & 0 \\
\hline Growth at $10^{\circ} \mathrm{C}$ & 100 & 100 & 100 & 100 & $\mathbf{0}$ & $\mathbf{0}$ \\
\hline Growth at pH 9.6 & 100 & 100 & 100 & 100 & 0 & 0 \\
\hline Survival at $60^{\circ} \mathrm{C}$ for $15 \mathrm{~min}$ & 100 & 100 & 100 & 75 & 75 & 100 \\
\hline Survival at $60^{\circ} \mathrm{C}$ for $1 \mathrm{~h}$ & 100 & 100 & 25 & 0 & 75 & 75 \\
\hline Hippurate hydrolysis & 90 & $\mathbf{0}$ & 0 & $12^{c}$ & 0 & 0 \\
\hline Growth with $6.5 \% \mathrm{NaCl}$ & 100 & 100 & 100 & 100 & 0 & $\mathbf{0}$ \\
\hline Growth at $4^{\circ} \mathrm{C}$ & 10 & 100 & 0 & 6 & 0 & 0 \\
\hline Acid from glycerol & 100 & 100 & 100 & 100 & 25 & $\mathbf{0}$ \\
\hline Acid from $d-(-)$-arabinose & 40 & 0 & 100 & 6 & 0 & $\mathbf{0}$ \\
\hline Acid from $l-(+)$-arabinose & 30 & 67 & 100 & 100 & 25 & 0 \\
\hline Acid from $d-(+)$-xylose & 40 & 0 & 100 & 100 & 0 & 0 \\
\hline Acid from $l-(-)$-xylose & 10 & 0 & 100 & 18 & 0 & 0 \\
\hline Acid from adonitol & $\mathbf{0}$ & 17 & 100 & 0 & 0 & 0 \\
\hline Acid from methyl xyloside & 0 & 0 & 0 & 6 & 0 & 0 \\
\hline Acid from $l-(-)$-sorbose & 10 & 0 & 100 & 0 & $\mathbf{0}$ & 0 \\
\hline Acid from rhamnose & 50 & 17 & 100 & 12 & $\mathbf{0}$ & 50 \\
\hline Acid from dulcitol & 0 & 17 & 0 & 6 & $\mathbf{0}$ & 25 \\
\hline Acid from meso-inositol & 70 & 0 & 0 & 12 & 0 & 25 \\
\hline Acid from mannitol & 100 & 33 & 100 & 100 & 50 & 50 \\
\hline Acid from sorbitol & 100 & 83 & 100 & 100 & 0 & 0 \\
\hline Acid from methyl- $d$-mannoside & 20 & 0 & 50 & 23 & 0 & 0 \\
\hline Acid from methyl- $d$-glucoside & 20 & $\mathbf{0}$ & 100 & 100 & 25 & 0 \\
\hline Acid from amygdalin & 100 & 100 & 100 & 100 & 75 & 100 \\
\hline Acid from arbutin & 10 & 100 & 100 & 100 & 75 & 100 \\
\hline Esculin hydrolysis $^{d}$ & 100 & 100 & 100 & 100 & 75 & 100 \\
\hline Acid from lactose & 100 & 100 & 100 & 100 & 100 & 0 \\
\hline Acid from $d-(+)$-melibiose & 0 & 50 & 25 & 100 & 100 & 0 \\
\hline Acid from sucrose & 80 & 67 & 50 & 100 & 100 & 50 \\
\hline Acid from $d$-(-)-trehalose & 100 & 83 & 100 & 100 & 25 & 25 \\
\hline Acid from inulin & 10 & 17 & 25 & 77 & 50 & 25 \\
\hline Acid from $d-(+)$-melezitose & 80 & $\mathbf{0}$ & 100 & 59 & 0 & 50 \\
\hline Acid from $d$-(+)-raffinose & 0 & $\mathbf{0}$ & 25 & 100 & 100 & 25 \\
\hline Acid from dextrin & 90 & 50 & 75 & 100 & 75 & 25 \\
\hline Acid from amylose & 0 & $\mathbf{0}$ & 0 & 12 & 0 & 25 \\
\hline Acid from starch & 100 & 67 & 25 & 100 & 100 & 0 \\
\hline Acid from glycogen & 10 & 0 & 0 & 6 & 75 & 0 \\
\hline Methyl red (API) ${ }^{d}$ & 80 & 100 & 100 & 94 & 100 & 75 \\
\hline DNase (API) ${ }^{d}$ & 10 & 0 & 0 & 0 & 0 & 25 \\
\hline Mucate $^{d}$ & 10 & 0 & 0 & 12 & 25 & 0 \\
\hline Gluconate $^{d}$ & 70 & $\mathbf{0}$ & 75 & 100 & 0 & 25 \\
\hline Lipase $^{d}$ & 40 & 67 & 100 & 88 & 50 & 100 \\
\hline Tetrathionate reductase $\mathrm{e}^{d}$ & 70 & 100 & 100 & $87^{c}$ & 100 & 100 \\
\hline Christensen citrate ${ }^{d}$ & 50 & 0 & 0 & 0 & 0 & 0 \\
\hline Malonate ${ }^{c}$ & 0 & 0 & 0 & 47 & 0 & 0 \\
\hline $\mathrm{Mol} \% \mathrm{G}+\mathrm{C}^{e}$ & 38.4 & 39.0 & 39.9 & $35.6,39.2$ & 39.3 & 35.6 \\
\hline
\end{tabular}

${ }^{a}$ All strains were positive for the following: growth at $45^{\circ} \mathrm{C}$; esculin hydrolysis; final pH in glucose broth below 4.25; growth with $40 \%$ bile; acid from ribose, galactose, glucose, fructose, mannose, $N$-acetyl glucosamine, salicin, cellobiose, and maltose. All strains were negative for the following: gelatin liquefaction; acid from erythritol; attack on pectate (in API); and utilization of acetate (in API).

${ }^{b}$ Positive strains were all alpha-hemolytic.

$c$ The reactions of the type strain are the majority reactions except for these tests.

d Tests (other than acidification of carbohydrates) performed in API galleries.

' Two strains of $S$. gallinarum (PB18, PB21) and one from each of the other species were examined. 
TABLE 2. Test results for $S$. oralis and similar organisms

\begin{tabular}{|c|c|c|c|c|}
\hline \multirow[b]{2}{*}{ Test } & \multicolumn{4}{|c|}{ \% Positive } \\
\hline & $\begin{array}{c}\text { S. mitis } \\
\text { (6 strains) }\end{array}$ & $\begin{array}{l}\text { S. sanguis } \\
\text { (3 strains) }\end{array}$ & $\begin{array}{l}\text { S. oralis sp. } \\
\text { nov. (13 } \\
\text { strains) }\end{array}$ & $\begin{array}{l}\text { "S. milleri" " } \\
\text { (3 strains) }\end{array}$ \\
\hline Hemolysis & 83 & 100 & 100 & 33 \\
\hline Nitrite reduction & $\mathbf{0}$ & 67 & $92^{c}$ & 67 \\
\hline Growth with $3 \% \mathrm{NaCl}$ & 100 & 100 & 0 & 67 \\
\hline Reduction of methylene blue & 100 & 0 & 8 & 67 \\
\hline Growth with sodium azide & 33 & $\mathbf{0}$ & 54 & 100 \\
\hline Reduction of tetrazolium & 67 & $\mathbf{0}$ & 100 & 67 \\
\hline Lysine decarboxylase & 0 & $\mathbf{0}$ & 85 & 33 \\
\hline Survival at $60^{\circ} \mathrm{C}$ for $15 \mathrm{~min}$ & 83 & 67 & 15 & 33 \\
\hline Growth with $0.0004 \%$ crystal violet & 0 & 0 & 100 & 33 \\
\hline Production of dextran & 17 & 100 & $31^{c}$ & 0 \\
\hline Acid from glycerol & 0 & 100 & 54 & $\mathbf{0}$ \\
\hline Acid from erythritol & 0 & 67 & 0 & $\mathbf{0}$ \\
\hline Acid from $d-(-)$-arabinose & 0 & 0 & 8 & $\mathbf{0}$ \\
\hline Acid from $l-(+)$-arabinose & $\mathbf{0}$ & 33 & 0 & 0 \\
\hline Acid from ribose & 50 & 67 & 92 & 100 \\
\hline Acid from $l-(-)$-sorbose & $\mathbf{0}$ & 33 & 0 & 0 \\
\hline Acid from rhamnose & 17 & 0 & 8 & 0 \\
\hline Acid from meso-inositol & $\mathbf{0}$ & 0 & 31 & $\mathbf{0}$ \\
\hline Acid from mannitol & 17 & 0 & 38 & 0 \\
\hline Acid from sorbitol & 17 & 0 & 23 & $\mathbf{0}$ \\
\hline Acid from methyl- $d$-mannoside & 17 & 0 & 15 & 0 \\
\hline Acid from methyl- $d$-glucoside & 50 & 33 & $38^{c}$ & $\mathbf{0}$ \\
\hline Acid from $N$-acetyl glucosamine & 100 & 100 & $92^{c}$ & 100 \\
\hline Acid from amygdalin & $\mathbf{0}$ & 67 & 15 & $\mathbf{0}$ \\
\hline Acid from arbutin & 0 & 33 & 38 & 33 \\
\hline Esculin hydrolysis $^{d}$ & $\mathbf{0}$ & 67 & 15 & 0 \\
\hline Acid from salicin & 67 & 67 & $54^{c}$ & 67 \\
\hline Acid from $d-(+)$-cellobiose & 33 & 67 & 31 & 33 \\
\hline Acid from lactose & 67 & 100 & 100 & 100 \\
\hline Acid from $d-(+)$-melibiose & 67 & 0 & $77^{c}$ & 33 \\
\hline Acid from sucrose & 83 & 100 & 100 & 100 \\
\hline Acid from $d$-(-)-trehalose & 17 & 100 & 77 & 100 \\
\hline Acid from inulin & 17 & 100 & 31 & 0 \\
\hline Acid from $d-(+)$-melezitose & 50 & 0 & 69 & 0 \\
\hline Acid from $d-(+)$-raffinose & 67 & $\mathbf{0}$ & $61^{c}$ & 0 \\
\hline Acid from dextrin & 100 & 67 & 77 & $\mathbf{0}$ \\
\hline Acid from starch & 50 & 33 & 31 & $\mathbf{0}$ \\
\hline Acid from glycogen & $\mathbf{0}$ & 33 & 23 & 0 \\
\hline Methyl red $^{d}$ & 50 & 33 & 38 & 0 \\
\hline DNase ${ }^{d}$ & 17 & 0 & 0 & 0 \\
\hline Gluconate $^{d}$ & 17 & 0 & 15 & 0 \\
\hline Lipase $^{d}$ & 33 & $\mathbf{0}$ & $61^{c}$ & 67 \\
\hline Tetrathionate reductase $^{d}$ & 17 & 33 & 92 & 100 \\
\hline $\mathrm{Mol} \% \mathrm{G}+\mathrm{C}^{e}$ & 38.9 & 39.3 & $39.9,40.0$ & 34.1 \\
\hline
\end{tabular}

a All strains were positive for the following: acid from galactose, glucose, fructose, mannose, and maltose. All strains were negative for the following: acid from $d-(+)$-xylose, $l-(-)$-xylose, adonitol, methyl- $d$-xyloside, dulcitol, amylose, and in the mucate, pectate, Christensen citrate, malonate and acetate tests in API.

${ }^{b}$ Positive strains were all alpha-hemolytic.

The reactions of the type strain are the majority reactions except for these tests.

d Tests (other than acidification of carbohydrates) performed in API galleries.

Two strains of S. oralis (PB179, PB183) and one from each of the other species were examined.

the different incubation times used. The difference in arginine hydrolysis may be due to the isomer used; the original method (9) and that in this study used the $d$ isomer of arginine, but Barnes et al. (2) used the $l$ isomer.

The difference in hippurate hydrolysis may be due in part to the limited number of strains tested by Barnes et al. (2). The resistance of these strains to $60^{\circ} \mathrm{C}$ is not high, although different times of testing prevent close comparison.

The reason for the difference in the type of hemolysis is not clear, but in our hands the 
TABLE 3. Growth of four strains of $S$. gallinarum on thallous acetate-tetrazolium agar over 9 days

\begin{tabular}{|c|c|c|c|c|}
\hline \multirow{2}{*}{ Growth after: } & \multicolumn{4}{|c|}{ Strain } \\
\hline & PB18 & PB19 & PB23 & PB24 \\
\hline Day $1\left(35^{\circ} \mathrm{C}\right)$ & Minimal growth & Minimal growth & Minimal growth & No growth \\
\hline $\begin{array}{l}\text { Days } 2 \text { through } 4 \\
\left(20^{\circ} \mathrm{C}\right)\end{array}$ & $\begin{array}{l}\text { Small pink } \\
\text { colonies }\end{array}$ & $\begin{array}{l}\text { Small pink } \\
\text { colonies }\end{array}$ & Minimal growth & $\begin{array}{l}\text { Small pink } \\
\text { colonies }\end{array}$ \\
\hline $\begin{array}{l}\text { Days } 5 \text { through } 9 \\
\left(20^{\circ} \mathrm{C}\right)\end{array}$ & $\begin{array}{r}\text { Moderate-sized } \\
\text { pink colonies }\end{array}$ & $\begin{array}{r}\text { Moderate-sized } \\
\text { pink colonies }\end{array}$ & $\begin{array}{c}\text { Small pink } \\
\text { colonies }\end{array}$ & $\begin{array}{r}\text { Moderate-sized } \\
\text { pink colonies }\end{array}$ \\
\hline
\end{tabular}

initial greening (alpha-hemolysis) at $16 \mathrm{~h}$ changed to clear zones after $48 \mathrm{~h}$; possibly some constituent in our medium inhibited hemolysis.

The strains of oral group II were found by Carlsson (3) to fall into several of his clusters, principally I and V (other strains of Carlsson's groups II and III clustered in our study close to $S$. salivarius, as expected from his study). Carlsson considered that his group I corresponded to Streptococcus sanguis and that group V was similar to but not identical with $S$. mitis (although some were beta-hemolytic or possessed the Lancefield group $\mathbf{G}, \mathrm{K}$, or $\mathrm{L}$ antigens). Our findings confirm the closeness of oral group II, $S$. sanguis, and $S$. mitis, and in addition indicate that " $S$. milleri" is closely allied (Fig. 1b). However, they also suggest that oral group II is not identical to any of these species. (The type strain of $S$. sanguis, NCTC 7863, and the authentic strains $S$. mitis NCTC 10712 and " $S$. milleri" NCTC 10708 were present in their respective clusters.)

Facklam (4) characterized two biovars of $S$. sanguis. He suggested that strains of $S$. sanguis II (esculin negative, produce acid from raffinose) and certain other dextran-producing, raffinosepositive strains of " $S$. mitior" represented a new taxon. The oral group II strains are mainly esculin negative and raffinose positive and may partly correspond with $S$. sanguis II, although only $31 \%$ of strains were found to produce dextran.

The two new species are formally proposed as follows.

Streptococcus gallinarum sp. nov. (gall-in$\mathrm{ar}^{\prime} \cdot$ um. L. fem. gen. pl. n. gallinarum, of hens).

Cells are gram-positive cocci in pairs or short chains, without capsules, and somewhat pleomorphic. They are nonmotile, nonsporing, aerobic and facultatively anaerobic, fermentative, and catalase-negative. Cells react with Lancefield group D antiserum. Grows slowly on thallous acetate-tetrazolium agar at room temperature, producing pink colonies. Hemolytic on horse blood agar, producing greening or complete lysis. $d$-Arginine is not hydrolyzed, and growth occurs at $45^{\circ} \mathrm{C}$ and $\mathrm{pH} \mathrm{9.6;} \mathrm{the} \mathrm{final} \mathrm{pH}$ in glucose broth is below 4.25. Shows growth with $6.5 \% \mathrm{NaCl}$. Other test reactions are shown in Table 1. Similar to "Streptococcus avium" but differs in being adonitol-negative, $l$-(-)-sorbose negative, raffinose positive, often malonate-positive, and reacts only with group $D$ antiserum. Mole percent $\mathrm{G}+\mathrm{C}, 37.4$. Found in intestines of domestic fowls. Type strain: F87/ $276(=$ PB21 $=$ NCTC 11428). The reactions of the type strain are the majority reactions for $S$. gallinarum given in Table 1, with the exceptions indicated by the footnote.

Streptococcus oralis sp. nov. (or'a' lis. M. L. adj. oralis, of the mouth).

Cells are gram-positive cocci in short chains, without capsules. They are nonmotile, nonsporing, aerobic and facultatively anaerobic, fermentative, and catalase negative. Hemolytic on horse blood agar, producing pronounced green-

TABLE 4. Comparison of the results of this study with those of Barnes et al. (2)

\begin{tabular}{|c|c|c|}
\hline \multirow[b]{2}{*}{ Test } & \multicolumn{2}{|c|}{$\%$ Positive } \\
\hline & $\begin{array}{l}\text { Barnes et al. } \\
\text { (37 strains) }\end{array}$ & $\begin{array}{l}\text { This study } \\
\text { (17 strains) }\end{array}$ \\
\hline Hemolysis (type) & 100 (beta) & $\begin{array}{l}100 \\
\text { (alpha) }\end{array}$ \\
\hline Growth with tellurite & 68 & 18 \\
\hline Arginine hydrolysis & 54 & 0 \\
\hline Methylene blue & 100 & 0 \\
\hline reduction & (10 days) & (1 day) \\
\hline Growth at $10^{\circ} \mathrm{C}$ & 92 & 100 \\
\hline Growth at $45^{\circ} \mathrm{C}$ & 98 & 100 \\
\hline Growth at pH 9.6 & 100 & 100 \\
\hline Hippurate hydrolysis & $100^{a}$ & 12 \\
\hline Esculin hydrolysis & 100 & 100 \\
\hline $\begin{array}{l}\text { Final pH in glucose } \\
\text { broth below } 4.3\end{array}$ & 100 & 100 \\
\hline Growth with $6.5 \mathrm{NaCl}$ & 100 & 100 \\
\hline Gelatin liquefaction & 0 & 0 \\
\hline Acid from lactose & 38 & $100^{b}$ \\
\hline Acid from mannitol & 54 & $100^{b}$ \\
\hline Acid from sorbitol & 8 & $100^{b}$ \\
\hline $\begin{array}{l}\text { Acid from } d-(+)- \\
\text { arabinose }\end{array}$ & 40 & $100^{b}$ \\
\hline Acid from raffinose & 98 & $100^{b}$ \\
\hline Acid from inulin & 54 & $77^{b}$ \\
\hline Acid from sucrose & 100 & $100^{b}$ \\
\hline Acid from starch & 0 & $100^{b}$ \\
\hline
\end{tabular}

${ }^{a}$ Not all strains tested.

${ }^{b}$ Tests performed in API galleries. 
ing ( $\alpha$-hemolytic). Reduces tetrazolium; grows with $0.0004 \%$ crystal violet; reduces tetrathionate. Other reactions are as in Table 2. Resembles Streptococcus sanguis but is usually esculin negative, raffinose positive, and does not grow with $3 \% \mathrm{NaCl}$. Mole percent $\mathrm{G}+\mathrm{C}, 39.9$. Found in the human mouth. The type strain is LVG 1 $(=\mathrm{PB} 182=$ NCTC 11427). The reactions of the type strain are the majority reactions for $S$. oralis given in Table 2 , with the exceptions indicated by the footnote.

\section{ACKNOWLEDGMENTS}

This work was supported by a Research Training Award to P.D.B. from the Medical Research Council.

We are grateful to E. M. Barnes and J. Carlsson for the strains examined and to M. J. Sackin of this Department for assistance with computing.

\section{LITERATURE CITED}

1. Barnes, E. M. 1956. Methods for the isolation of faecal streptococci (Lancefield group D) from bacon factories. $\mathbf{J}$. Appl. Bacteriol. 19:193-203.

2. Barnes, E. M., G. C. Mead, C. S. Impey, and B. W. Adams. 1978. The effect of dietary bacitracin on the incidence of Streptococcus faecalis subsp. liquefaciens and related streptococci in the intestines of young chicks. Brit. Poultry Sci. 19:713-723.

3. Carlsson, J. 1968. A numerical taxonomic study of human oral streptococci. Odontologisk Revy 19:137-160.
4. Facklam, R. R. 1977. Physiological differentiation of viridans streptococci. J. Clin. Microbiol. 5:184-201.

5. Feltham, R. K. A., A. K. Power, P. A. Pell, and P. H. A. Sneath. 1978. A simple method for storage of bacteria at $-76^{\circ} \mathrm{C}$. J. Appl. Bacteriol. 44:313-316.

6. Garvie, E. I. 1976. Hybridization between the deoxyribonucleic acids of some strains of heterofermentative lactic acid bacteria. Int. J. Syst. Bacteriol. 26:116-122.

7. Guthof, O. 1956. Ueber pathogene "vergrunende Streptokokken.” Zentralbl. Bakteriol. Parasitenkd. Infektionskr. Hyg. Abt. 1 Orig. Reihe A 166:553-564.

8. Jones, D. 1978. Composition and differentiation of the genus Streptococcus, p. 1-49. In F. A. Skinner and L. B. Quesnel (ed.), Streptococci. Academic Press Inc., London.

9. Niven, C. F., K. L. Smiley, and J. M. Sherman. 1942. The hydrolysis of arginine by streptococci. J. Bacteriol. 43:651-660.

10. Nowlan, S. S., and R. H. Deibel. 1967. Group Q streptococci. I. Ecology, serology, physiology, and relationship to established enterococci. J. Bacteriol. 94:291-296.

11. Skerman, V. B. D., V. McGowan, and P. H. A. Sneath (ed.). 1980. Approved lists of bacterial names. Int. J. Syst. Bacteriol. 30:225-420.

12. Sneath, P. H. A. 1977. A method for testing the distinctness of clusters: a test of the disjunction of two clusters in Euclidean space as measured by their overlap. J. Math. Geol. 9:123-143.

13. Sneath, P. H. A. 1979. BASIC program for a significance test for two clusters in Euclidean space as measured by their overlap. Computers \& Geosciences 5:143-155.

14. Sneath, P. H. A., and R. R. Sokal. 1973. Numerical taxonomy. W. H. Freeman and Co., San Francisco. 